\title{
The Political Economy of Federalism in Nigeria, by Dele Babalola (Switzerland, AG: Palgrave Macmillan, 2019), 180 pp. ISBN 978-3-030- 05493-9
}

\author{
Kennedy Ohazuruike, \\ Doctoral Candidate, Department of Political Science \& International Relations, Nile University of \\ Nigeria, Abuja
}

Federalism is considered as the best arrangement suited to keeping together whether centripetally or centrifugally different peoples, groups, countries or/and nationalities for the purpose of immediate and far good. Whether it is undertaken for security reasons, for peace sake, for administrative reasons or for Economic reasons, it recognizes particular and general authority and autonomy. Federalism was adopted and accepted in Nigeria as the best condition for the over 300 ethnic groups in Nigeria to stay together. At its inception before independence in Nigeria, it was seen as the most acceptable mode of organizing Nigeria. Later on, Federalism which was the reason for the different groups in Nigeria to come together became the reason for their struggles. Various authors have delved into how this happened. Among them and of great importance is the book discussing the political economy of federalism in Nigeria.

The book seeks to expose the influence of economic politics (control of Nigeria's resources) on Nigerian Federalism. The author analyzed this through the Historical, Regional and Ethnic rivalry perspectives (p.15), including constitutional formation and reformation that has taken place since Nigerian Federalism. According to the book, the contradictions and failures in Nigerian Federalism accentuate its political economy. The book lay bare the interplay between politics and economy tracing it from the beginning of the struggle for the formation of a federal state in Nigeria to the regionalization politics that gave birth to the Midwest region, to the first coup, the return of democracy (fourth republic) and the various conferences and panels that culminated in the 2014 National Conference. In the end, the book observed that economic benefits had been the reason for politics. This historical exposal is an eye-opener to the underlying cause for the low development or realization of proper or true Federalism in Nigeria. 
Using the Rentier theory, the book explained how the oil boom that would have raised Nigeria to an enviable position among the committee of Nations was the main force pressing down the country from making any headway. The book exposed how the discovery of oil and its attendant boom and the inability of successive governments in Nigeria to manage this aspect of her economy without losing sight of other parts of the economy like Agriculture (p.155), transformed Nigeria into a mono-economy. What was left for the country since then is the struggle for who controls this single economy and since the acquisition of power was the easiest way to own/control this aspect of the country's life, the struggle for power became marred with all sought of death warrants and corruption. Corruption has grown and eaten deep into the fabrics of the national life that the political will to respond to the primary tenant of Federalism like equitable distribution of the resources, the security of life and property and proper health care has become luxury other than the normal.

The book also recognised the different efforts by different governments to fight or manage the problems resulting from the mono-economy, unitary and do or die politic that has hunted the Nigerian Federalism. Efforts such as the Federal Character Principle and Quota System (p. 138), State Creation (p.135) and the different National Conferences that have taken place since the return of democracy in Nigeria, have been accepted and promoted as means of enhancing and mitigating the problem of Nigeria federalism (p.147). However, the author argued that all these efforts failed and even backfired because the fundamental aspects of federalism that are supposed to be addressed, like decentralisation, reviewing her fiscal federalism, going beyond the mono-economy to a multi-economic system, are being overlooked. These basic federal principles have received different voices by different groups under different nature. This incldes the Resource Control agitations of the Niger Delta group, the secession moves of the Indigenous People of Biafra (IPOB) of south-east and the insurgency of Boko Haram in the northeast.

There is no doubt that federalism in Nigeria has achieved its aim of holding together multiple ethnic groups. Still, it has failed in its political distribution, which for the author is a vital part of a federal system. What is a federal Nigeria, if mutual suspicion still exists and even worse among the major ethnic groups, much more the minor ethnic groups? Why should Nigeria always be referred to as a federal state when the executive's visible overbearing posture over the judiciary and the legislature is so pronounced? In addition to the author's positions, Nigerian federalism can be argued to have failed as long as she is unable to lift herself off the Rentier position. Nigeria's federalism has failed as long as her derivation principle remains a time bomb and as long as state governments remain the appendage of the federal government. 